\title{
Will shrinking body size and increasing species diversity of crustaceans follow the Warming of the Arctic litoral?
}

\author{
Jan Węsławski ${ }^{1}$, Joanna Legezynska ${ }^{1}$, and Maria Wlodarska- Kowalczuk ${ }^{2}$ \\ ${ }^{1}$ Institute of Oceanology PAS \\ ${ }^{2}$ Polish Academy of Sciences Institute of Oceanology
}

May 5, 2020

\begin{abstract}
Over thirty species of littoral marine Gammaridea occur along the coasts of the North Atlantic. From one to several species can coexist in a single region. There is an evident, inverse relationship between egg incubation time and temperature (from 14 to $>120$ days) and consequent trends in the size of the animals on reaching maturity (from $5 \mathrm{~mm}$ in warmer waters to $30 \mathrm{~mm}$ in the coldest ones) and in lifespan (from $<6$ months to $>5$ years). Littoral gammarids are a good example of the shrinking size effect of increasing temperatures and size-related species diversity. In large species the annual cohorts of the population (3 to 5 annual size groups) functionally replace the adults of smaller species. The ongoing warming of the European Arctic seas may extend the distribution limits of boreal species so that more Gammarus species may appear on northern coasts hitherto occupied by just one or at most two species.
\end{abstract}

\section{Introduction}

Temperature is widely regarded as a key factor both directly and indirectly responsible for the diversity of marine fauna. The usual patterns show species richness increasing from cold towards warmer regions among the majority of taxa, at least in the Palearctic and Nearctic (Gaston 1998, 2000). In poikilotherms, temperature directly controls metabolism and growth rates, and hence, the size of an organism. Species diversity is usually negatively correlated with the size of an organism, that was well documented on terrestrial insects (Siemann et al. 1996). That is why the temperature increase due to global warming is likely to cause a change in average individual size, or selection towards smaller species in communities (Atkinson \& Sible 1997). Such a pattern has already been demonstrated in pelagic Copepoda (Beaugrand et al. 2000), but it is not yet universal in benthic communities (Mazurkiewicz et al. 2020). The blurred size pattern among soft-bottom benthos is due to the dominance of polychaete worms and bivalves - two groups in which linear growth is difficult to assess. Peracaridan crustaceans, on the other hand, are likely to be the best model taxon for studies of temperature-related size changes. Peracaridans have no larval stage, and juveniles grow throughout life, with the successive moults clearly demarcating the increments. Egg incubation time, egg size and gammarid female size are inversely related to temperature (see the review in Steele \& Steele 1975). In addition, not only low temperatures but also oxygen levels are responsible for the large size of cold-water Crustacea, a phenomenon known as "polar gigantism" (Chapelle \& Peck 1999).

Atlantic sector of the Arctic is warming very fast (ACIA 2005), mainly due to the increasing advection of Atlantic waters (Walczowski et al. 2012) that brings boreal species North of their previous limits of distribution (Berge et al 2005, Beuchel et al. 2006, Fleisher et al 2007, Weslawski et al. 2018).

Here, we hypothesize that a larger body size (associated with perennial longevity) in northern littoral Gammarus populations reduces the possibility of sibling species occurring sympatrically, as observed at present in warmer waters. We explore this by comparing diversity and size in Gammarus populations inhabiting 
rocky North Atlantic coasts across latitudes from 45 to $81^{\circ} \mathrm{N}$ and water temperatures from -1.8 to $25^{\circ} \mathrm{C}$. We expect that present-day patterns of distribution are likely to change, as the temperature increase will tend to shorten gammarid life cycles in the Subarctic. Such a phenomenon has already been observed in pelagic Crustacea, where the same species - Calanus finmarchicus - may produce from one generation in cold water to three in temperate seas per year, depending on the ambient temperature (Irigoien et al. 2000).

\section{Material and methods}

The original material comes from the unpublished archive of the first author, who sampled littoral Gammarus species in the Gulf of Gdańsk (Baltic Sea, $54^{\circ} \mathrm{N}$ ) and Hornsund fjord (Svalbard Archipelago, $77^{\circ} \mathrm{N}$ ) in 19791982. They were collected with a hand-net on the shore, at 0-1 m depth, from under stones and algae. The animals were measured from the tip of the head to the tip of telson, excluding spines. Formalin-preserved specimens were wet-weighed after having been blotted on filter paper. The temperatures for the different localities were obtained from the cited references or meteorological data currently available on the Internet. Some of the materials collected by the first author were presented in the form of an unpublished manuscript - an MSc thesis at the University of Gdańsk (Wolska 1983).

Summer minimal temperature for the geographic region was taken as a critical value for marine poikilotherms (Golikov et al. 1990). The occurrence of the sympatric species was assessed for the region (sea) from the literature cited, species names were checked after Bellan-Santini and Costello (2001).

\section{Results and discussion}

At least thirty sibling species from Gammarus and other species from closely related genera (Marinogammarus, Pontogammarus, Dikerogammarus etc.) occur in the intertidal of both the eastern and western North Atlantic (Table 1). Their size at maturity ranges from 4 to $52 \mathrm{~mm}$ and is related to lifespan and ambient temperature (Fig. 1). Length frequencies in the summer samples of the Arctic population of two sympatric sibling Gammarus species indicate that there are three annual cohorts, or fourteen size groups (2 mm intervals) (Fig. 2). Compared to the Arctic, the temperate water population (Baltic) of the same species in summer (after the death of the winter cohort and juvenile release in spring) has a cohort of one age (length $6-15 \mathrm{~mm}$ ) that corresponds to five size groups $(2 \mathrm{~mm}$ intervals). The summer length frequency of the large $(40 \mathrm{~mm})$ species in the Arctic gives up to twenty size groups (2 mm intervals).

The growth in two very different populations of the same species (G. oceanicus from the Baltic and Arctic, summer temperatures plus $20{ }^{\circ} \mathrm{C}$ and $4{ }^{\circ} \mathrm{C}$ respectively) is similar, although the cold water population lives longer and grows to greater lengths (Fig. 3). A cold water individual may not reach maturity in the first year of its life, but will grow continuously for the next one or two years, ultimately attaining a large size.

If the life cycle is to be completed within a year or less, the critical phenomenon is the egg incubation time (Table 1). The relationship of this time to ambient temperature has been studied many times in poikilotherms like fish and crustaceans, as well as specifically in the genus Gammarus (Steele and Steele 1975, Whiteley et al. 2011). Incubation in Gammarus setosus or G. wilkitzkii lasts 120 and more days in cold, Subarctic - Arctic waters, at year round temperatures $<2^{\circ} \mathrm{C}$ (Steele \& Steele 1974, Weslawski \& Legeżyńska 2002). In the Black Sea or southern Baltic, by contrast, summer generations of Gammarus inaequicauda and $G$. salinusincubate eggs at temperatures $>20^{\circ} \mathrm{C}$ in less than 20 days (Jażdżewski 1970). The ability to shorten the egg incubation period is probably governed by temperature only (as observed in Calanuscopepods Irigoien et al. 2000 or pelagic hyperids - Koszteyn et al. 1995). Other factors controlling the size of these invertebrates are the availability and quality of food and/or oxygen saturation (Chapelle \& Peck 1999). Adults of Gammarus species are omnivores (Tzvetkova 1975) and food availability is not a limiting factor in the littoral (plant detritus, meiofauna and microorganisms are plentiful; Weslawski et al. 1993). The oxygen concentration in coastal waters is always high, or even supersaturated, as there the water dynamics is the highest.Gammaru s species have adequate food resources, a high level of oxygen and an appropriate range of salinity. The only limiting factor is suitable microhabitat, i.e. stones or crevices under which they can hide from predators. Gammarids are a preferred dietary constituent of coastal fish in the Baltic (MacNeil et al. 1999), and of fish, seabirds and seals on Svalbard (Weslawski \& Kulinski 1989, Lydersen et al. 1994). The 
interstices among loose stones, providing adequate shelter, are quickly filled when some hundreds of animals are trying to hide beneath one of them (Weslawski 1994). It is the occupation of this microhabitat by large, local species that is the likely factor preventing boreal, eurytopic species from successfully colonizing the North. Ca 300 large specimens (mean length $20 \mathrm{~mm}$ ) or 2000 small ones (mean length $5 \mathrm{~mm}$ ) can conceal themselves under a stone $400 \mathrm{~cm}^{2}$ in area; this corresponds with the average densities reported for Arctic localities (300-500/ $\mathrm{m}^{2}$ ) (Weslawski 1994) and for temperate sites, where the number of small gammarid species can exceed $10000 / \mathrm{m}^{2}$ (Tzvetkova 1975).

Niche selection and competition was described as a critical factor for the new species colonisation in littoral amphipods (Piscart et al. 2008, Kotta et al. 2013).

The majority of marine littoral gammarids display a very wide tolerance to salinity and temperature (Tzvetkova 1975). In the North Atlantic intertidal, many different species occur in the temperature range between $0^{\circ} \mathrm{C}$ in winter to $>20^{\circ} \mathrm{C}$ in summer. Consequently, most of the species listed in Table 1 , have a potentially very wide geographical distribution. If temperature were the only factor limiting their occurrence, the North Atlantic coast would be divided into a narrow zone with cold stenothermic Gammarus species (Gammarus wilkitzkii and G. setosus), with the rest of the area supporting the other, eurytopic species. In actual fact, however, the littoral gammarids are spatially more limited, and the number of species corresponds inversely to their size and life length (Table 1, Fig. 1). In the Arctic, where the two large, cold-water species (G. wilkitzkii and G. setosus ) co-occur, there is almost no sympatric occurrence, as G. wilkitzkii is an ice-associated species and G. setosus is a littoral species. However, when the ice melts in coastal waters, $G$. wilkitzkii seeks the same shelter as its littoral congener (Weslawski 1994, Polterman 1997). Another example of regions where two large species occur together is Canada and Svalbard, where the local cold-water $G$. setosus is confronted with the boreal G. oceanicus. On Newfoundland, the coasts of which have an extensive tidal range from three to twelve metres, G. setosus was recorded higher up on the shore and G. oceanicus lower down (Steele \& Steele 1974). On Spitsbergen, the two species co-exist recently, as the G. oceanicus is colonising the area after the glacial retreat (Grabowski et al. 2019).

In the littoral, when a species is large, there are many size groups that act as separate ecological units: size variations in gammarids lead to differences in mobility, food and behaviour (see Weslawski et al. 2010). All the available space is occupied and the number of true species is limited - to two, according to published observations. In areas where species are small, there are fewer size groups and more species can co-exist (up to fourteen in a region like the Mediterranean Sea, Table 1).

The sympatric occurrence discussed here is considering the regional scale (gamma diversity). The co- occurrence on a small scale of one sample, alpha diversity is difficult to assess, as there are very few data. In the Baltic, where 9 local plus four alien (man introduced) species occur, the actual occurrence of three to five species in one spot was confirmed (Jażdżewski 1970, own observations).

As the size of gammarids is so closely related to ambient temperature, we may speculate that with increasing coastal temperatures in the Arctic, littoral gammarids will complete their life cycle at a smaller size, which will create opportunities for the area's colonization by southern species. This will be a direct effect not of temperature (those eurytopic species are already capable of living there) but of the favourable size structure of competitors.

In summary, two phenomena are well documented in littoral Gammarus species. One is the direct relationship of temperature to lifespan and the size of an adult animal: at warmer temperatures, all known species grow faster and reach maturity at a smaller size. The other is the low number of sympatric species in areas where large species occur, and the high number of such species where the animals are small. From these two observations we can infer that climate change may shift the boreal species northwards, where competition from large species will be reduced as the temperature rises.

\section{Acknowledgements}

Preparation of this publication was supported by funds from the Svalbard Miljovern SIP Project - RIS No. 
3243, Polish Ministry for Higher Education funds SPUB, the project ACCES - Belmont Fund project, the ADAMANT-DAINA project and the Polish Norwegian Research Funding Mechanism (project DWARF).

\section{Data availability statement}

All data presented in this paper are available through the project web page ACCEShttps://www.iopan.pl/projects/Acces/(operational since June 2020).

\section{REFERENCES}

ACIA (2005). Impacts of a warming Arctic: Arctic Climate Impact Assessment. Cambridge University Press, New York.

Atkinson D., Sibly R.M. (1997). Why are organisms usually bigger in colder environments ? Making sense of life history puzzle. TREE12, 235- 239

Beaugrand G., Ibanez F., Reid PC (2000). Spatial seasonal and long term fluctuations of plankton in relation to hydroclimatic features in the English Channel, Celtic Sea and Bay of Biscay. Marine Ecology Progress Series 200, 93-102

Bellan-Santini, D., \& Costello, M.J. (2001). Amphipoda. in: Costello, M.J. et al. (Ed.) (2001). European register of marine species: a check-list of the marine species in Europe and a bibliography of guides to their identification. Collection Patrimoines Naturels 50: pp. 295-308.

Berge J., Johnsen G., Nilsen F., Gulliksen B., \& Slagstad D. (2005). Ocean temperature oscillations enable reappearance of blue mussels Mytilus edulis in Svalbard after a 1000 year absence.Marine Ecology Progress Series, 303, 167-175.

Beuchel F., Gulliksen B., \& Carroll M.L. (2006). Long-term patterns of rocky bottom macrobenthic community structure in an Arctic fjord (Kongsfjorden, Svalbard) in relation to climate variability (1980-2003). Journal of Marine Systems , 63, 35-48.

Bousfield E.L. (1969). New records of Gammarus (Crustacea: Amphipoda) from the Middle Atlantic Region, Chesapeake Science 10 (1):1-17.

Chapelle G., Peck L.S. (1999). Polar gigantism dictated by oxygen availability. Nature 399, 114-115

Dobrzycka-Krahel, A. Kendzierska, H. Szaniawska, A. (2013). Ponto-Caspian gammarids - new species in the Gulf of Gdańsk (Southern Baltic Sea), Journal of Ecology and Health 17(3), 110-114.

Fleischer D., Schaber M., \& Piepenburg D. (2007). Atlantic snake pipefish (Entelurus aequoreus ) extends its northward distribution range to Svalbard (Arctic Ocean). Polar Biology , 30, 1359-1362.

Fredette T.J., R. J. Diaz. (1986). Life history of Gammarus mucronatus Say (Amphipoda: Gammaridae) in warm temperate estuarine habitats, York River, Virginia, Journal of Crustacean Biology6(1): 57-78.

Gable M.F., R. A. Croker, (1977). The Salt Marsh Amphipod,Gammarus palustris Bousfield, 1969 at the Northern Limit of its Distribution I. Ecology and Life Cycle. Estuarine and Coastal Marine Sciences 5: 123-134.

Gaston K.J. (1998). Species- range size distributions: products of speciation, extinction and transformation. Pr. Trans. Royal Soc.B, 353

Gaston K.J. (2000). Global patterns of biodiversity. Nature 405, 220-227

Golikov A.N., Dolgolenko M.A., Maximovich N.N., Scarlato O.A. (1990). Theoretical approaches to marine biogeography. Marine Ecology Progress Series 63; 289- 301

Grabowski M., Jabłońska A., Weydmann-Zwolicka A., Gantsevich M., Strelkov P., Skazina M., Węsławski J.M. (2019). Contrasting molecular diversity and demography patterns in two intertidal amphipod crustaceans reflect Atlantification of High Arctic. Marine Biology 166, 155 
Greze I. 1985, , Higher Crustacea, Fauna Ukrainy, 26, Naukova Dumka, Kijev,

Grintsov V.A. (2009). A New Amphipod Species Echinogammarus Karadagiensis Sp. N. (Amphipoda, Gammaridae) From Crimean Coasts (Black Sea, Ukraine), Vestnik Zoologii, 43(2): 23-26

Grintsov, V.A. (2016). Dynamics of population structure of two species of Echinogammarus genus (Gammaridae, Amphipoda) from Laspi Bay (Crimea, Black Sea), Marine Biological Journal 1 No 3: 22-26.

Gurjanova E.P. (1951). Amphipoda Gammaridea from the seas of the USSR and vicinity. Opredeliteli Faune SSSR pp. 1-1029. Zoologicheskii Institut Akademii Nauk SSSR.

Irigoien X., Head RM., Cummings D., Harbour D. (2000). Feeding selectivity and egg production of Calanus helgolandicus in the English Chanel. Limnology and Oceanography 45, 44-54

Jażdżewski K. (1970). Biology of Crustacea Malacostraca in the Bay of Puck, Polish Baltic Sea. Zoological Poloniae 20, 423-480.

Koszteyn J., Timofeev S., Weslawski JM., Malinga B. (1995). Size structure of Themisto abyssorum Boeck and T. libellulaMandt populations in European-Arctic Seas. Polar Biology 15, 85-92

Kotta J., Pärnoja M., Katajisto T., Lehtiniemi M., Malavin S. A., Reisalu G., \& Panov V. E. (2013). Is a rapid expansion of the invasive amphipod Gammarus tigrinus Sexton, 1939 associated with its niche selection: a case study in the Gulf of Finland, the Baltic Sea.

Lincoln R. J. (1979). British marine Amphipoda: Gammaridea. British Museum of Natural History, London, 658pp.

MacNeil C., Dick J.T.A., \& Elwood R.W. (2007). The dynamics of predation on Gammarus spp. (Crustacea: Amphipoda).Biological Reviews 74, 375-395.

Mazurkiewicz M., Górska B., Renaud P., Włodarska-Kowalczuk M. (2020). Latitudinal consistency of biomass size spectra - benthic resilience despite environmental, taxonomic and functional trait variability. Scientific Reports 10:4164, https://doi.org/10.1038/s41598-020-60889-4

Piscart C., Maazouzi C., \& Marmonier P. (2008). Range expansion of the North American alien amphipod Gammarus tigrinus Sexton, 1939 (Crustacea: Gammaridae) in Brittany, France. Aquatic Invasions 3 (4), 449-453.

Poltermann M. (1987). Franz Josef Land amphipods. Berichte zum Polarforschung AWI

Siemann E., Tilman D., Haarstad J. (1996). Insect species diversity abundance and body size relationships. Nature 380, 704- 706.

Steele D. H., And V. J. Steele 1970 The Biology Of Gammarus(Crustacea, Amphipoda) In The Northwestern Atlantic. Iv. Gammarus lawrencianus Bousfield. Can. J. Zool. 48: 1261-1267.

Steele D.H., \& Steele V.J. (1974). The biology of Gammarus(Crustacea, Amphipoda) ln the north-western Atlantic. VIII. Geographic distribution of the northern species. Canadian Journal of Zoology52, 1115-1120.

Steele D.H., \& Steele V.J. (1975). The biology of Gammarus(Crustacea, Amphipoda) in the north-western Atlantic. XI. Comparison and discussion. Canadian Journal of Zoology 53, 1116-1126.

Steele V.J., \& Steele D.H. (1970). The biology of Gammarus(Crustacea, Amphipoda) in the north-western Atlantic. II. Gammarus setosus Dementieva. Canadian Journal of Zoology 48, 659-671.

Steele V.J., \& Steele D.H. (1972). The biology of Gammarus(Crustacea, Amphipoda) in the north-western Atlantic. V. Gammarus oceanicus Segerstråle. Canadian Journal of Zoology 50, 801-813.

Tzvetkova N.L. (1975). Coastal waters gammarids from the North and Far East seas of the USSR and adjacent waters, Nauka, Leningrad, pp 258. 
Walczowski W., Piechura J., Goszczko I., \& Wieczorek P. (2012). Changes in Atlantic water properties: an important factor in the European Arctic marine climate. ICES Journal of Marine Science 69, 864-869.

Węsławski J.M. \& Legeżyńska J. (2002). Life cycles of some Arctic amphipods. Polish Polar Research 23, 253-264.

Węsławski J.M. (1994). Gammarus (Crustacea, Amphipoda) from Svalbard and Franz Josef Land. Distribution and density. Sarsia79, 145-150.

Węsławski J.M., Kuliński W. (1989). Notes on fishes in Hornsund fjord area (Spitsbergen). Polish Polar Research 10, 241-250.

Węsławski J.M., Opanowski A., Legeżyńska J., Maciejewska B., Włodarska-Kowalczuk M, Kędra M. (2010). How many roles can a species play? Hidden diversity in Arctic crustaceans. Pol. Polar Research31, 205-216.

Węsławski J.M., Wiktor J., Zajączkowski M., \& Swerpel S. (1993). Intertidal zone of Svalbard: Macroorganism distribution and biomass. Polar Biology 13, 73-79.

Węsławski JM, Dragańska-Deja K, Legeżyńska J, Walczowski W (2018). Range extension of a boreal amphipod Gammarus oceanicus in the warming Arctic. Ecol Evol 8(15):7624-7632.doi:10.1002/ece3.4281

Whiteley N.M., Rastrick S.P.S., Lunt D.H., \& Rock J. (2011). Latitudinal variations in the physiology of marine gammarid amphipods. Journal of Experimental Marine Biology and Ecology 400, 70-77.

Zettler M.L., Zettler A. ( 2017). Marine And Freshwater Amphipoda From The Baltic Sea And Adjacent Territories. Conchbooks, Harxheim, Germany Pp. 846

\begin{tabular}{lllllll}
\hline Table 1 Gammaridae from Atlantic region & region & minimal & max. & min. & max. & life \\
\hline & considered & female & length & summer & summer & span \\
water & adult & water \\
temp. & \\
species/population & & & & temp. & ${ }^{\circ}$ C & yrs \\
Chaetogammarus olivii (H. Milne Edwards, 1830) & Black, Medit. & 6 & 12 & 15 & 20 & 1 \\
Chaetogammarus warpachowskyi Sars, 1897 & Baltic & 5 & 7 & 10 & 10 & 1 \\
Dikerogammarus haemobaphes (Eichwald, 1841) & Azov, Black & 8 & 20 & 15 & 20 & 1 \\
Dikerogammarus haemobaphes (Eichwald, 1841) & Baltic & 10 & 22 & 10 & 20 & 1 \\
Dikerogammarus villosus (Sowinsky, 1894) & Baltic & 8 & 30 & 10 & 15 & 2 \\
Echinogammarus finmarchicus (Dahl, 1938) & White & 10 & 21 & 5 & 15 & 1 \\
Echinogammarus foxi (Schellenberg, 1928) & Mediterr. & 6 & 8 & 15 & 25 & 1 \\
Echinogammarus ischnus (Stebbing, 1899) & Baltic & 6 & 15 & 10 & 20 & 1 \\
Echinogammarus ischnus (Stebbing, 1899) & Black & 5 & 10 & 15 & 20 & 1 \\
Echinogammarus karadagiensis Grintsov, 2009 & Black & 4 & 6 & 15 & 25 & 0,5 \\
Echinogammarus marinus (Leach, 1815) & North, W Atl. & 15 & 25 & 5 & 15 & 1 \\
Echinogammarus obtusatus (Dahl, 1938) & North, W Atl. & 9. & 20. & 5 & 15 & 1 \\
Echinogammarus pirloti (Sexton \& Spooner, 1940) & North & 11 & 14 & 10 & 15 & 0,5 \\
Echinogammarus planicrurus (Reid, 1940) & North & 5 & 9 & 10 & 20 & 1 \\
Echinogammarus stoerensis (Reid, 1938) & North, W Atl. & 4 & 8 & 10 & 20 & 0,5 \\
Gammarus aequicauda (Martynov, 1931) & Black, Medit. & 10 & 20 & 15 & 25 & 1 \\
Gammarus annulatus Smith, 1873 & W Atl. & 10 & 20 & 5 & 15 & 1 \\
Gammarus chevreuxi Sexton, 1913 & North, E Atl. & 6 & 13 & 10 & 20 & 0,5 \\
Gammarus crinicornis Stock, 1966 & Mediterr. & 8 & 20 & 15 & 25 & 1 \\
Gammarus crinicornis Stock, 1966 & Black & 10 & 20 & 15 & 25 & 1 \\
Gammarus daiberi Bousfield, 1969 & W Atl. & 8 & 12,5 & 5 & 20 & 1 \\
Gammarus duebeni Lilljeborg, 1852 & North, Baltic & 8 & 22 & 10 & 20 & 1
\end{tabular}




\begin{tabular}{lllllll}
\hline Table 1 Gammaridae from Atlantic region & region & minimal & max. & min. & max. & life \\
\hline Gammarus duebeni Lilljeborg, 1852 & White & 12 & 25 & 5 & 15 & 1 \\
Gammarus inaequicauda Stock, 1966 & North, Baltic & 8 & 10 & 10 & 20 & 1 \\
Gammarus insensibilis Stock, 1966 & E Atl., Med.., Black & 5 & 21 & 15 & 25 & 1 \\
Gammarus lacustris G.O. Sars, 1863 & E Atl., Baltic & 10 & 25 & 10 & 15 & 1 \\
Gammarus lawrencianus Bousfield, 1956 & W Atl. & 5 & 10 & 5 & 15 & 0,5 \\
Gammarus locusta (Linnaeus, 1758) & E. Atl., North & 15 & 33 & 10 & 20 & 2 \\
Gammarus locusta (Linnaeus, 1758) & Baltic & 12 & 18 & 10 & 20 & 2 \\
Gammarus mucronatus Say, 1818 & W Atl. & 1 & 4 & 5 & 30 & 0,5 \\
Gammarus oceanicus Segerstråle, 1947 & Atlantic & 11 & 38 & 5 & 20 & 2 \\
Gammarus oceanicus Segerstråle, 1947 & Baltic & 10 & 30 & 10 & 20 & 2 \\
Gammarus palustris Bousfield, 1969 & W Atl. & 4 & 14 & 5 & 25 & 1 \\
Gammarus pulex (Linnaeus, 1758) & Baltic & 12 & 23 & 10 & 15 & 1 \\
Gammarus salinus Spooner, 1947 & E Atl. & 12 & 24 & 10 & 20 & 1 \\
Gammarus salinus Spooner, 1947 & Baltic & 10 & 24 & 10 & 25 & 2 \\
Gammarus setosus Dementieva, 1931 & Arctic & 13 & 44 & 0 & 15 & 3 \\
Gammarus subtypicus Stock, 1966 & Black & 6 & 20 & 15 & 25 & 1 \\
Gammarus tigrinus Sexton, 1939 & North, Baltic & 4 & 14 & 10 & 25 & 1 \\
Gammarus wilkitzkii Birula, 1897 & Arcic & 20 & 52 & 0 & 5 & 5 \\
Gammarus zaddachi Sexton, 1912 & E Atl., & 10 & 20 & 10 & 25 & 1 \\
Gammarus zaddachi Sexton, 1912 & Baltic & 7 & 30 & 10 & 30 & 1 \\
Obesogammarus crassus (G. O. Sars, 1894) & Baltic & 7 & 15 & 10 & 15 & 1 \\
Pontogammarus robustoides (G.O. Sars, 1894) & Baltic, North & 12 & 22 & 10 & 20 & 1 \\
\hline
\end{tabular}

\section{Hosted file}

Multispecies_Fig2.docx available at https://authorea.com/users/303572/articles/433753-willshrinking-body-size-and-increasing-species-diversity-of-crustaceans-follow-the-warmingof-the-arctic-litoral

\section{Hosted file}

Multispecies-fig1.docx available at https://authorea.com/users/303572/articles/433753-willshrinking-body-size-and-increasing-species-diversity-of-crustaceans-follow-the-warmingof-the-arctic-litoral

\section{Hosted file}

Multispecies_fig3.docx available at https://authorea.com/users/303572/articles/433753-willshrinking-body-size-and-increasing-species-diversity-of-crustaceans-follow-the-warmingof-the-arctic-litoral 